\title{
The Predictive Value of Combining Leach Sign and Serum Progesterone in Diagnosis of Undisturbed Ectopic Pregnancy
}

\author{
ASEM A. MOUSSA, M.D.*; WAEL R. HABLAS, M.D.**; MOHAMED K. ETMAN, M.D.*** and \\ SAID A. SHABAN, M.Sc. ${ }^{* * *}$ \\ The Department of Obstetrics \& Gynecology, Faculty of Medicine, Azhar* and Ain Shams*** Universities and \\ The Department of Clinical Pathology**, Faculty of Medicine, Azhar University
}

\begin{abstract}
Background: Ectopic Pregnancy is a dangerous complication of early gestation. In low-income nations it is considered one of the chief causes of maternal mortality. The majority of mortalities occur briefly after hospital admission making ectopic pregnancy a prominent public health issue.

Patients and Methods: The current research study was a prospective observational in fashion conducted in the fetal Medicine Department at Ain Shams University Maternity Hospital and involved 100 cases consecutively admitted with clinical symptoms and signs indicative of an ectopic pregnancy.

Results: Cases with Leash sign had ststistically significant lower progesterone level and more frequent ectopic pregnancy. ( $p$-values $<0.001)$. Ectopic pregnancy cases had statistically significant lower progesterone serum level and more frequent leash sign. ( $p$-values $<0.001)$. There was statistical significant high agreement level between existence of Leash sign and ectopic pregnancy diagnosis. ( $p$-value $<0.001,95 \% \mathrm{CI}=0.9451$ eash sign, true negative $=75.0 \%$, false negative $=0.0 \%$, true positive $=23.0 \%$, false positive $=2 \%$.
\end{abstract}

Conclusion: Leash sign is a highly sensitive sonographic sign that could be implemented on widespread practice however other sonographic markers should be respected in integration with bio markers since there is no single sign or marker that could be applicable in all case scienarios.

Key Words: Serum progesterone - Undisturbed ectopic pregnancy.

\section{Introduction}

ECTOPIC pregnancies are gestations abnormally located outside the normal intrauterine location, leading to considerable maternal morbidity and mortality. It is a cornerstone issue and a crucial task of the clinician to ascertain that the gestation is normally located within the uterus and viable.

Correspondence to: Dr. Asem Anwar Moussa, The Department of Obstetrics \& Gynecology, Faculty of Medicine, Azhar University
When required tools and an experienced Sonographer are available in a low-income regions of service pelvic sonography could aid by early detectability of free abdominal fluid of a leaking ectopic pregnancy. On the other hand, of an intrauterine pregnancydetection clinical presence of ectopic pregnancy unlikely. Sonography is correlated with earlier clinical diagnosis in various research studies in tertiary centres in low income communities [1-5].

Leash sonographic sign is an eccentric leash of vessels having low resistance flow on spectral Doppler suggestive of trophoblastic tissue. This sign have a sensitivity of $100 \%$, a specificity of $99 \%$, a PPV of $95 \%$ and an NPV of $100 \%$ [6-10] .

This sign mostly depends on the abnormal implantation and tubal trophoblast invasion causing marked blood flow changes in the adjacent supplying vessels. The sign have 3 constituents: (1) Grayscale identification of an adnexal abnormality (e.g, a swollen tube or a ring-like structure suggestive of an EP); (2) A linear artery supplying the tube at one point; (3) A low-resistance placental type of flow on spectral Doppler interrogation of the above artery. With fulfillment of the above criteria, a sensitivity of $100 \%$ and a specificity of $98 \%$ have been reported in the diagnosis of an early EP in a limited number of cases [11-15].

However, an overlap was shown to be present in an ovary with a mature cystic teratoma, therefore, this sign still needs to be verified both with larger series and various ovarian pathologies. Color Doppler is most helpful when an EP is not seen, but highly suspected. At that time, Doppler imaging can be used to find a mass representing an ectopic pregnancy [16-20] 
Maternal progesterone is initially secreted by corpus luteum then by the placental tissue, and Causes normal physiologic development of the endometrial lining, uterine development and growth, sufficient uterineblood supply, and uterine preparation for the process of labor [21-25].

Progesterone serum levels are revealed to be decreased in both ectopic gestations and other abnormally developing intrauterine pregnancies, in comparison to viable intra uterine pregnancies. Considerable number of research studies have been conducted for the usage of progesterone both as a single biomarker and in multiple marker integrated for usage in diagnosis of ectopic pregnancy [2630].

A recent research meta-analysis revealed that at a cut-off values from 3.2 to $6 \mathrm{ng} / \mathrm{mL}$, serum progesterone level has a predictability value in non-viable pregnancy with a statistically obtained sensitivity of $74.6 \%$ and a statistically obtained specificity of $98.4 \%$, however it was not capable to discriminate adequately ectopic pregnancy from other abnormal forms of intra uterine pregnancies. Cases with pregnanacies of unkown locations with progesterone $\leq 10 \mathrm{nmol} / \mathrm{L}$ at presentation are at low risk of needing medical intervention and might not benefit from attending routine clinical follow-up visits [31-35].

Aim:

To assesess predictability and diagnostic efficacy of sonographic leash sign in ectopic pregnancy alone and in conjunction with serum progesterone.

\section{Patients and Methods}

The current research study was a prospective observational in fashion conducted in the fetal Medicine Department at Ain Shams University Maternity Hospital from 2014-2018 and involved 100 cases consecutively admitted with clinical symptoms and signs indicative of an ectopic pregnancy (Pelvic pain, bleeding per vagina and/or amenorrhea) during, the cases age ranged from 1842 years and the period of amenorrhea had a range from 4-10 weeks. Exclusive research criteria for ectopic pregnancy where as follows: Existence laboratory or sonographic evidence of intrauterine pregnancy, low resistance intrauterine flow on doppler suggestive of a recent gestational loss, non-visualization of an ectopic pregnancy within the adnexal anatomical zone, retained products of conception. Exclusive research criteria for the current study have been as follows; a negative pregnancy test, a positive. HCG serum level under the pregnancy level, and/or no amenorrhea, clinically and Vitally haemodynamically unstable cases.

All study subjects have been subjected to the following: Full clinical history taking and clinical examination with meticulous care have been conducted to those cases having clinical signs of a ruptured ectopic pregnancy that were haemodynamically compromised in order to have immediate surgical intervention without delay and a sonographic examination. Blood sample collection was performed for (beta HCG and serum progesterone levels with simultaneous sonographic examination was conducted in order to save time. Initial trans abdominal and transvaginal real time sonographic examination have been conducted for every case via conventional B-mode, tissue harmonic imaging, color Doppler and power Doppler scanning by usage of LOGIQ 5 (G.E. Medical Systems, Seoul, Korea) machine with $5 \mathrm{MHZ}$ trans abdominal and 6.5 MHZ transvaginal probes for any sonographic signs of ectopic pregnancy: Blood sign: An inhomogenous mass adjacent to the ovary and moving separately from it, Bagel sign: A mass with a hyper-echoic ring around the gestational sac, a gestational sac with a fetal pole with or without cardiac activity. Color Doppler assessment for the adnexae and the artery supplying any observed masses. At the time of sonographic examination the (beta HCG serum values were obtained. The sonographic diagnosis was then correlated with the beta HCG indices.

\section{Statistical analysis:}

The collected research data were coded, tabulated, and statistically analyzed using SPSS program (Statistical Package for Social Sciences) software version 17.0. Descriptive statistics were conducted for numerical parametric research data as mean $\pm \mathrm{SD}$ (standard deviation) and minimum $\&$ maximum of the range and for numerical non parametric data as median and $1 * \& 3$ rd interquartile range, while they were done for categorical research data as number and percentage.Inferential analyses was conducted for quantitative research variables by usage of the independent $t$-test in cases of two independent groups with parametric research $\mathrm{f}$ data and Mann Whitney $U$ in cases of two independent groups with non research parametric data. Inferential statistical analyses have been performed for qualitative research data using Chi square test for independent research groups. The level of significance was taken at $p$-value $<0.050$ is significant, otherwise is non significant. The $p$-value is a statistical measure for the probability that the results observed in a study could have occurred by chance. 


\section{Ethical approval:}

The research study was conducted after approval from the Ethical Committee of the Department of Obstetrics and Gynecology, Faculty of Medicine, Al-Azhar University. Written consent was conducted from all study subjects before recruitment in the study after explanation of the purpose and procedures of the study.

\section{Results}

Table (1): Demographic characteristics of the studied cases.

\begin{tabular}{lcl}
\hline & Mean \pm SD & \multicolumn{1}{c}{ Range } \\
\hline Age (years) & $28.3 \pm 5.0$ & $18.0-39.0$ \\
BMI $\left(\mathrm{kg} / \mathrm{m}^{2}\right)$ & $25.5 \pm 1.4$ & $22.8-28.7$ \\
Parity & $1.4 \pm 1.2$ & $0.0-4.0$ \\
Amennorrhea period (weeks) & $7.0 \pm 1.2$ & $4.0-10.0$ \\
\hline
\end{tabular}

Total $=100$

Table (1) shows demographic characteristics of the studied cases mean \pm SD age (years), BMI $\left(\mathrm{Kg} / \mathrm{m}^{2}\right)$, parity, amenorrhea period (weeks) $=$ $28.3 \pm 5.0,25.5 \pm 1.4,1.4 \pm 1.2,7.0 \pm 1.2$ consecutively.

Table (2): Sonographic findings and laboratory investigations of the studied cases.

\begin{tabular}{lcc}
\hline & Mean \pm SD & Range \\
\hline Progestrone $(\mathrm{ng} / \mathrm{mL})$ & $19.5 \pm 11.6$ & $1.6-47.3$ \\
& $\mathrm{~N}$ & $\%$ \\
Leash sign: & & \\
Present & 25 & 25.0 \\
Absent & 75 & 75.0 \\
\hline Total $=100$ & &
\end{tabular}

Table (2) and Fig. (1) show that: Serum Progesterone mean $\pm \mathrm{SD}=19.5 \pm 11.6$ Leash sign was in $25 \%$ of the studied cases. Ectopic pregnancy was in $23 \%$ of the studied cases.

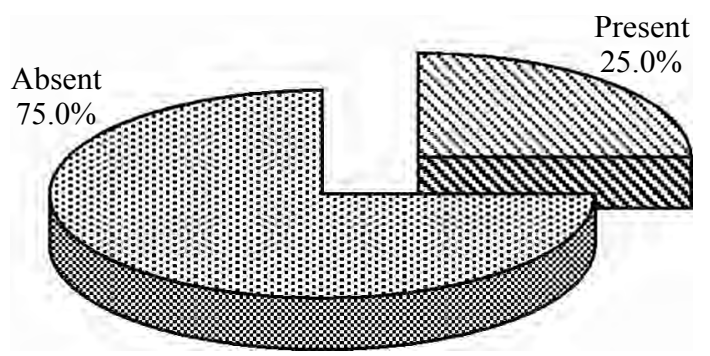

Fig. (1): Leash sign among the studied cases.

Table (3): Ectopic pregnancy among the studied cases.

\begin{tabular}{lcc}
\hline & Mean \pm SD & Range \\
\hline Ectopic & 23 & 23.0 \\
Not ectopic & 77 & 77.0 \\
\hline
\end{tabular}

Total $=100$
Table (3) and Fig. (2) show that: Ectopic pregnancy was in less than quarter if the studied cases (23\% of cases).

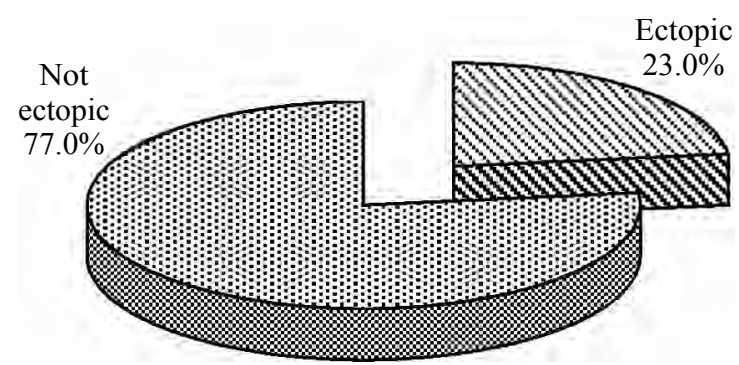

Fig. (2): Ectopic pregnancy among the studied cases.

Table (4): Comparison according to Leash sign.

\begin{tabular}{|c|c|c|c|}
\hline Variables & $\begin{array}{l}\text { Present } \\
(\mathrm{N}=25)\end{array}$ & $\begin{array}{l}\text { Absent } \\
(\mathrm{N}=75)\end{array}$ & $p$ \\
\hline Age (years) & $27.3 \pm 4.8$ & $28.6 \pm 5.0$ & $\wedge^{\wedge} 0.257$ \\
\hline BMI $\left(\mathrm{kg} / \mathrm{m}^{2}\right)$ & $25.7 \pm 1.5$ & $25.5 \pm 1.3$ & $\wedge^{\wedge} 0.559$ \\
\hline Parity & $1.2 \pm 1.2$ & $1.5 \pm 1.3$ & $\wedge^{\wedge} 0.355$ \\
\hline $\begin{array}{l}\text { Amennorrhea } \\
\text { period (weeks) }\end{array}$ & $6.9 \pm 1.3$ & $7.1 \pm 1.1$ & $\wedge^{\wedge} 0.471$ \\
\hline Progestrone $(\mathrm{ng} / \mathrm{mL})$ & $7.8 \pm 8.9$ & $23.4 \pm 9.6$ & $\wedge<0.001 *$ \\
\hline \multicolumn{4}{|l|}{ Ectopic: } \\
\hline Ectopic & $23(92.0 \%)$ & $0(0.0 \%)$ & $\#<0.001 *$ \\
\hline Not ectopic & $2(8.0 \%)$ & $75(100.0 \%)$ & \\
\hline
\end{tabular}

Table (4) and Figs. $(3,4)$ show that: Cases with Leash sign had ststistically significant lower progesterone level and more frequent ectopic pregnancy. ( $p$-values $<0.001$ ). Ectopic pregnancy cases had statistically significant lower progesterone serum level and more frequent leash sign. ( $p$-values $<0.001)$. Mean serum progesterone in ectopic versus not ectopic ( $7.1 \pm 8.9$ vs. $23.2 \pm 9.6)$. Leash sign $100.0 \%$ of cases of ectopic pregnancy only $2.6 \%$ of non ectopic cases.

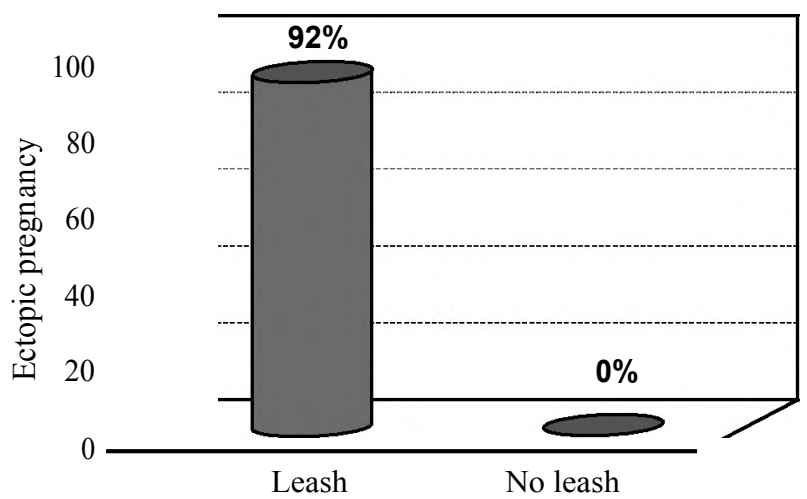

Fig. (3): Comparison according to Leash sign regarding ectopic pregnancy. 


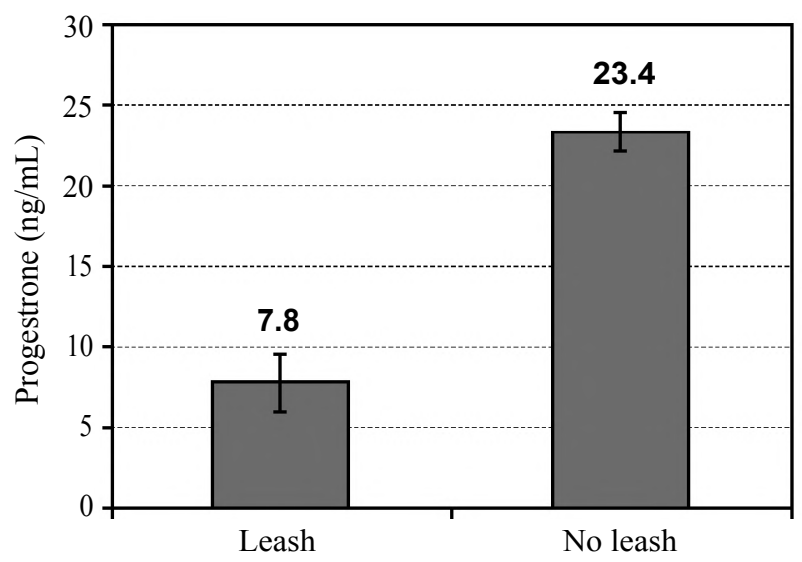

Fig. (4): Comparison according to Leash sign regarding serum progesterone.

Table (5): Comparison according to Ectopic pregnancy.

\begin{tabular}{|c|c|c|c|}
\hline Variables & $\begin{array}{l}\text { Ectopic } \\
(\mathrm{N}=23)\end{array}$ & $\begin{array}{l}\text { Not ectopic } \\
\quad(\mathrm{N}=77)\end{array}$ & $p$ \\
\hline Age (years) & $27.0 \pm 4.9$ & $28.6 \pm 5.0$ & ${ }^{\wedge} 0.167$ \\
\hline BMI $\left(\mathrm{kg} / \mathrm{m}^{2}\right)$ & $25.6 \pm 1.5$ & $25.5 \pm 1.3$ & $\wedge 0.721$ \\
\hline Parity & $1.3 \pm 1.2$ & $1.5 \pm 1.3$ & $\wedge^{\wedge} 0.433$ \\
\hline $\begin{array}{l}\text { Amennorrhea } \\
\text { period (weeks) }\end{array}$ & $7.0 \pm 1.3$ & $7.1 \pm 1.2$ & ${ }^{\wedge} 0.738$ \\
\hline Progestrone $(\mathrm{ng} / \mathrm{mL})$ & $7.1 \pm 8.9$ & $23.2 \pm 9.6$ & ${ }^{\wedge}<0.001 *$ \\
\hline \multicolumn{4}{|l|}{ Ectopic: } \\
\hline Present & $23(100.0 \%)$ & $2(2.6 \%)$ & $\#<0.001^{*}$ \\
\hline Absent & $0(0.0 \%)$ & $75(97.4 \%)$ & \\
\hline
\end{tabular}

Table (5) and Fig. (5) show that: Ectopic pregnancy cases had significant lower progesterone and more frequent leash sign.

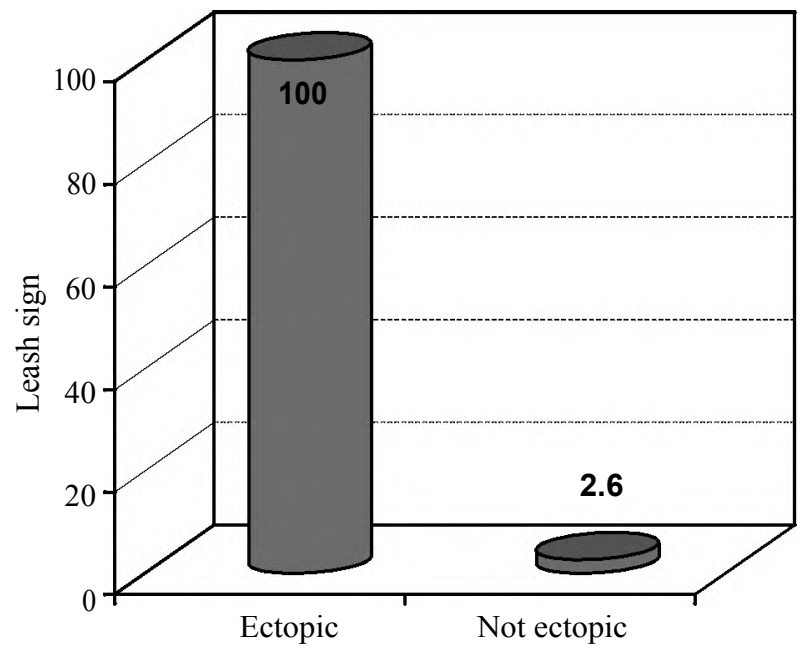

Fig. (5): Comparison according to ectopic pregnancy regarding leash sign.

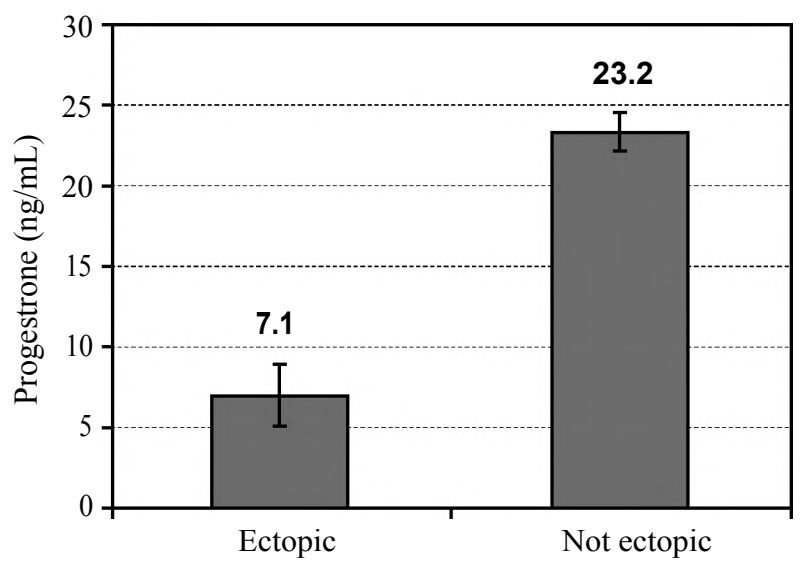

Fig. (6): Comparison according to ectopic pregnancy regarding progesterone.

Table (6): Agreement between Leash sign and ectopic pregnancy diagnosis.

\begin{tabular}{|c|c|c|c|}
\hline \multirow{2}{*}{ Leash } & \multicolumn{2}{|c|}{ Ectopic } & \multirow{2}{*}{ Total } \\
\hline & Present & Absent & \\
\hline Present & $23(23.0 \%)^{\mathrm{TP}}$ & $2(2.0 \%) \mathrm{FP}$ & $25(25.0 \%)$ \\
\hline Absent & $0(0.0 \%) \mathrm{FN}$ & $75(75.0 \%) \mathrm{TN}$ & $75(75.0 \%)$ \\
\hline Total & $23(23.0 \%)$ & $77(77.0 \%)$ & $77(100.0 \%)$ \\
\hline $\begin{array}{l}\text { Kappa } \\
(95 \% \mathrm{CI})\end{array}$ & 0.9 & $p<0.0$ & $1 *$ \\
\hline
\end{tabular}

Percentages are from the total (100).

TP: True positive. $\quad$ FP: False positive.

TN: True negative. FN: False negative.

There was statistical significant high agreement level between existence of Leash sign and ectopic pregnancy diagnosis. ( $p$-value $<0.001,95 \% \mathrm{CI}=$ 0.945 leash sign, true negative $=75.0 \%$, false negative $=0.0 \%$, true positive $=23.0 \%$, false positive $=2 \%$.

Table (7): Diagnostic performance of serum progesterone in the diagnosis of ectopic pregnancy.

\begin{tabular}{lccccc}
\hline Factors & AUC SE & $p$ & $95 \%$ CI & Cut off \\
\hline Progesterone 0.888 & 0.051 & $<0.001 *$ & $0.787-0.989$ & - \\
\hline AUC: Area under curve. & CI: Confidence interval. & \\
SE : Standard error. & *: Significant. &
\end{tabular}

Table (7) and Fig. (7): Serum progesterone level had statistically significant moderate diagnostic performance in the diagnosis of ectopic pregnancy. In which Area under curve $=0.888$, Standard error $=0.051,95 \%$ Confidence interval $=0.787-0.989, p$-value $<0.001$. 


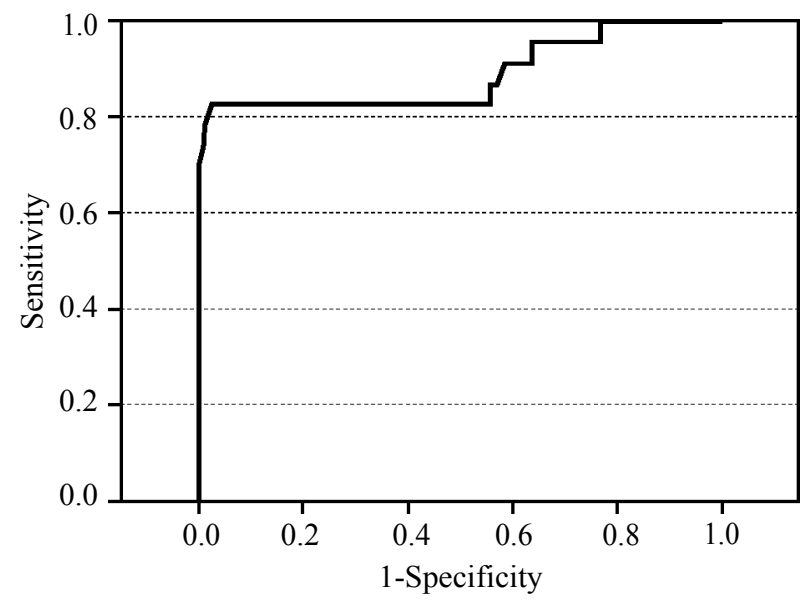

Fig. (7): ROC curve for serum progesterone in the diagnosis of ectopic pregnancy.

Table (8): Diagnostic characteristics of optimum serum progesterone cutoff points and Leash sign in the diagnosis of ectopic pregnancy.

\begin{tabular}{|c|c|c|c|c|}
\hline Characters & Value & $95 \% \mathrm{CI}$ & Value & $95 \% \mathrm{CI}$ \\
\hline & \multicolumn{2}{|c|}{ Leash sign } & \multicolumn{2}{|c|}{ Progesterone $<4.8 \mathrm{ng} / \mathrm{mL}$} \\
\hline Sensitivity & $100.0 \%$ & $85.2 \%-100.0 \%$ & $82.6 \%$ & $61.2 \%-95.0 \%$ \\
\hline Specificity & $97.4 \%$ & $90.9 \%-99.7 \%$ & $97.4 \%$ & $90.9 \%-99.7 \%$ \\
\hline DA & $98.0 \%$ & $93.0 \%-99.8 \%$ & $94.0 \%$ & $87.4 \%-97.8 \%$ \\
\hline Youden's index & $97.4 \%$ & $93.8 \%-101.0 \%$ & $80.0 \%$ & $64.1 \%-95.9 \%$ \\
\hline PPV & $92.0 \%$ & $74.0 \%-99.0 \%$ & $90.5 \%$ & $69.6 \%-98.8 \%$ \\
\hline NPV & $100.0 \%$ & $95.2 \%-100.0 \%$ & $94.9 \%$ & $87.5 \%-98.6 \%$ \\
\hline $\mathrm{LR}+$ & 38.50 & $9.80-151.18$ & 31.80 & $8.00-126.49$ \\
\hline LR- & 0.00 & $0.00-0.00$ & 0.18 & $0.07-0.44$ \\
\hline LR & $>100.0$ & $>100.0->100.0$ & 178.13 & $30.33-1046.22$ \\
\hline \multirow[t]{3}{*}{ Kappa } & 0.945 & $0.870-1.020$ & 0.825 & $0.691-0.960$ \\
\hline & \multicolumn{2}{|c|}{ Leash sign then } & & \\
\hline & \multicolumn{2}{|c|}{ Progesterone $<4.8 \mathrm{ng} / \mathrm{mL}$} & & \\
\hline Sensitivity & $82.6 \%$ & $61.2 \%-95.0 \%$ & & \\
\hline Specificity & $100.0 \%$ & $95.3-100.0 \%$ & & \\
\hline DA & $96.0 \%$ & $90.1 \%-98.9 \%$ & & \\
\hline Youden's index & $82.6 \%$ & $67.1 \%-98.1 \%$ & & \\
\hline PPV & $100.0 \%$ & $82.4 \%-100.0 \%$ & & \\
\hline NPV & $95.1 \%$ & $87.8 \%-98.6 \%$ & & \\
\hline $\mathrm{LR}+$ & $>100.0$ & $>100.0->100.0$ & & \\
\hline LR- & 0.17 & $0.07-0.42$ & & \\
\hline LR & $>100.0$ & $>100.0->100.0$ & & \\
\hline Kappa & 0.880 & $0.765-0.994$ & & \\
\hline
\end{tabular}

CI : Confidence interval.

YI : Youden's index.

NPV: Negative Predictive value.

DA : Diagnostic accuracy.

LR+: Positive likelihood ratio.

PPV: Positive Predictive value.

LR-: Negative likelihood ratio.

LR : Diagnostic odd ratio

Leash sign had better characteristics than progesterone $<4.8 \mathrm{ng} / \mathrm{mL}$, if both added perfect sensitivity decreased while the specificity became perfect. In which leash sign alone sensitivity $=100 \%$, specificity $=97.4 \%$, while progesterone alone at a cut off value $<4.8 \mathrm{ng} / \mathrm{mL}$ had a sensitivity $=82.6 \%$, specificity $=97.4 \%$. On the other hand if both were added, sensitivity $=82.6 \%$, specificity $=100.0 \%$. 


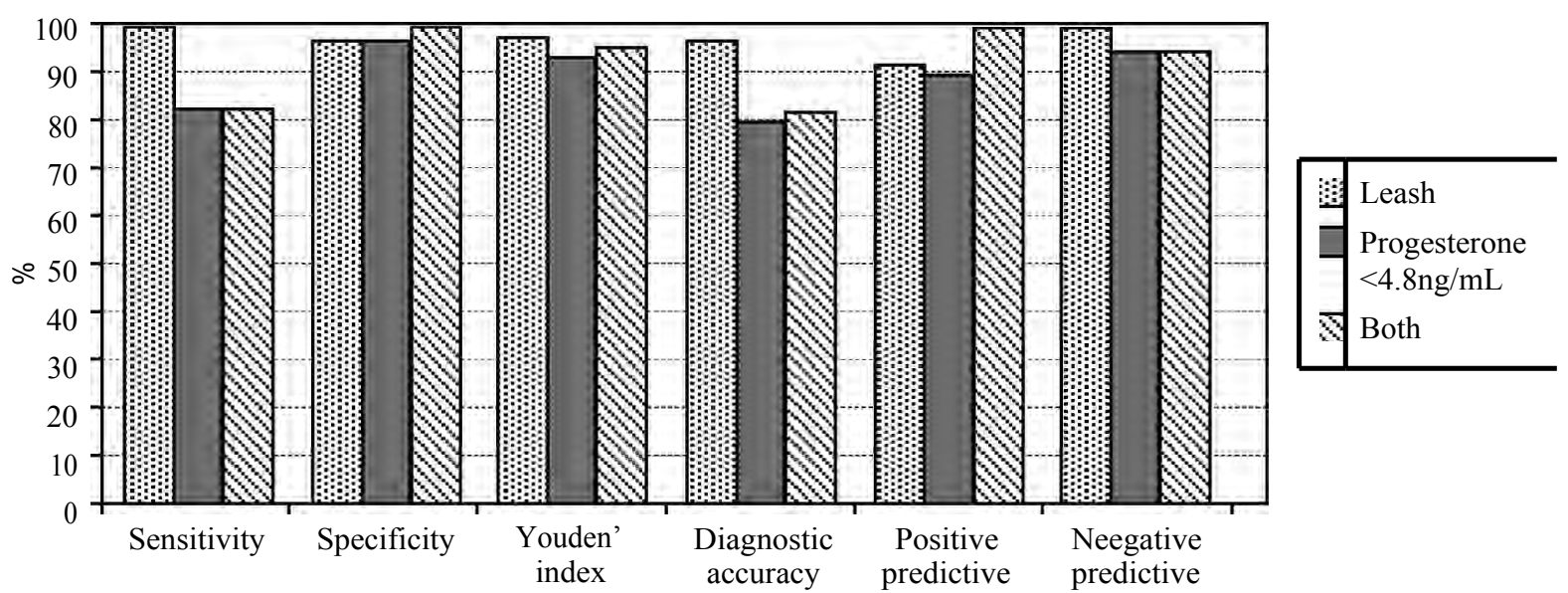

Fig. (8): Diagnostic characteristics of optimum serum progesterone cutoff points and Leash sign in the diagnosis of ectopic pregnancy.

\section{Discussion}

Ectopic Pregnancy is a dangerous complication of early gestation. In low-income nations it is considered one of the chief causes of maternal mortality, however the precise incidence rates are unidentified, due to common clinical misdiagnosis. In high-income nations early clinical diagnosis could usually be performed by usage of sonography and human chorionic gonadotropin serum level. In low income nations, reaching the proper clinical diagnosis is more complex, and delay in clinical diagnosis could exist before and after physician consultation. Leash sign is an eccentric leash of vessels having low resistance flow on spectral Doppler suggestive of trophoblastic tissue [36-42]

The current research study was a prospective observational in manner conducted in the fetal Medicine Department at Ain Shams University Maternity Hospital and involved 100 cases consecutively admitted with clinical symptoms and signs indicative of an ectopic pregnancy (Pelvic pain, bleeding per vagina and/or amenorrhea) during, the cases age ranged from $18-42$ years and the period of amenorrhea had a range from 4-10 weeks.

The current research results revealed and displayed the following, in which demographic characteristics of the studied cases mean \pm SD age (years), BMI $\left(\mathrm{Kg} / \mathrm{m}^{2}\right)$, parity, amenorrhea period $($ weeks $)=28.3 \pm 5.0,25.5 \pm 1.4,1.4 \pm 1.2,7.0 \pm 1.2$ consecutively. As regards: Investigations of the studied cases, Serum Progesterone mean $\pm \mathrm{SD}=$ $19.5 \pm 11.6$ Leash sign was in $25 \%$ of the studied cases. Ectopic pregnancy was in $23 \%$ of the studied cases.

Cases with Leash sign had ststistically significant lower progesterone level and more frequent ectopic pregnancy. ( $p$-values $<0.001$ ). Ectopic pregnancy cases had statistically significant lower progesterone serum level and more frequent leash sign. ( $p$-values $<0.001)$. Mean serum progesterone in ectopic versus not ectopic (7.1 \pm 8.9 vs . $23.2 \pm 9.6)$. Leash sign $100.0 \%$ of cases of ectopic pregnancy only $2.6 \%$ of non ectopic cases. There was statistical significant high agreement level between existence of Leash sign and ectopic pregnancy diagnosis. ( $p$-value $<0.001,95 \% \mathrm{CI}=0.945$ leash sign, true negative $=75.0 \%$, false negative $=0.0 \%$, true positive $=23.0 \%$, false positive $=2 \%$.

Serum progesterone level had statistically significant moderate diagnostic performance in the diagnosis of ectopic pregnancy. In which Area under curve $=0.888$, Standard error $=0.051,95 \%$ Confidence interval $=0.787-0.989, p$-value $<0.001$.

Leash sign had better characteristics than progesterone $\leq 4.8 \mathrm{ng} / \mathrm{mL}$, if both added perfect sensitivity decreased while the specificity became perfect. In which leash sign alone sensitivity $=100 \%$, specificity $=97.4 \%$, while progesterone alone at a cut off value $\leq 4.8 \mathrm{ng} / \mathrm{mL}$ had a sensitivity $=82.6 \%$, specificity $=97.4 \%$. On the other hand if both were added, sensitivity $=82.6 \%$, specificity $=100.0 \%$.

A similar research study to assess the efficiency of transvaginal Doppler sonography for the diagnosis of ectopic pregnancy. Conducted over 3 years, on 100 cases with signs indicative of a likely ectopic pregnancy were assesed with transvaginal sonography and Doppler examination. Fallopian tubes were evaluated for the existence of lowresistance arterial flow. The research team obtained the following results in which of the 100 cases, 19 patients had ectopic pregnancies. That was similar to the current research study results. It was revealed that all Patients of ectopic gestations had a charac- 
teristic eccentric leash of vessels on color Doppler examination that Revealed and displayed a low resistance placental type of flow on spectral Doppler. The research team concluded that a new reliable sign of ectopic pregnancy named the leash sign, had a sensitivity of $100 \%$ and specificity of $99 \%$, a positive predictive value of $95 \%$ and negative predictive value of $100 \%$, thus aiding in the diagnosis of early ectopicpregnancy, and resulting in earlier management intervention with decreased morbidity and mortality the current research have shown similar results although serum progesterone was used that was not implemented by $[\mathbf{1 , 2 , 1 0 ]}$

Another research study was conducted previously on the basis that sonographic diagnosis of ectopic gestation have been made easy particularly by the usage of Doppler sonography. In which the previous research studies revealed that existence of peri-trophoblastic blood flow by Doppler sonography and the observation of a low-resistance, high-velocity flow pattern were proven as specific sonographic sign for trophoblastic tissue. The research team conducted a study with the aim to assess the efficiency of Doppler sonographic examination in the predictability of management success in tubal gestations being administered with single dosage of conservative methotrexate. The research team recruited a cohort of 104 cases with non-ruptured ectopic gestation that were hemodynamically stable and candidates for methotrexate management. The spectral wave form of the mass was categorised according to the vascularization density by Power Doppler sonography and that form of classification wasn't used in the current research study. It was categorised as Grade 1, 2 and 3, consecutively. All cases received a single $50 \mathrm{mg} / \mathrm{m}^{2}$ dosage of systemic methotrexate. Serum 3 HCG levels were assayed on the 4 th and 7 th days of tmanagement. The management was considered unsuccessful in cases without a reduction of $15 \%$ or more in the serum levels of beta HCG between days 0 and 7 of starting treatment. The following results were obtained in which Twenty-four cases with grade I vascularity, 11 cases with grade II vascularity and 13 cases with grade III vascularity were referred as Group I, II and III, consecutively, in accordance to the degree of adnexal vascularity evaluated by Doppler sonography. On the whole success rate of methotrexate management was revealed to be $72.9 \%$. The rates of management clinical response to systemic methotrexate administration in cases with Grade I, II and III ectopic getstational mass vascularization were revealed to be $58.3 \%, 81.8 \%$ and $92.3 \%$, consecutively. Comparitive analysis of the research groups' management responses shown that a linear- by-linear correlation with the Chi-square test. That there is raised vascularizationgrade of ectopic pregnancy was correlated with a higher likelihood of response to methotrexate management treatment. The research team have came to the conclusion that observing and assessing the vascularization grade with Doppler sonography could beconsidered a remarkable tool in predictability of management success considering its ease of usage and low cost $[15,17,20]$

Another research study previously conducted to identify the preoperative sonographic parameters and indices for evaluation of the size of tubal ectopic gestation that link best with findings at surgical intervention. The research study was conducted in a prospective manner of all for all cases attending the center were the research was conducted who had a conclusive transvaginal sonographic diagnosis of tubal ectopic gestation over a 10-month time period. In each patient, the total size of the ectopic Gestation was measured by locating the calipers on the outer edges of the visible trophoblastic tissue. In ectopic gestations presenting with a well-defined gestational sac, the size of the chorionic cavity was in addition evaluated by usage of the inner borders of the trophoblastic ring as reference points. In cases having signs of intra-abdominal bleeding, the parameters of the hematosalpinx and/or hemoperitoneum was taken for evaluation. Surgeons were blinded to the sonographic measurements and have been asked to estimate the dimensions of the ectopic gestation and the volume of hemoperitoneum during the operation. The research team of investigators recruited a cohort of 105 study subjects diagnosed having a tubal ectopic gestation on sonographic examination, in which 71 cases $(67.6 \%)$ were managed by surgical intervention. A statistically significant ( $p$-value $<0.01)$ positive correlation have been revealed between all sonographic parameters and the size of the tubal ectopic gestation as recorded during surgical intervention. In the nonexistence of hematosalpinx, the mean entire outer diameter of the ectopic gestation had the greatest positive correlation with the tubal ectopic pregnancy size at surgical intervention ( $p$-value $<0.001)[25,32,41]$.

In clinical scenarios complicated by hematosalpinx, the mean diameter of the fallopian tube was the only research variable that was interrelated statistically significantly with the Calculated size of the ectopic gestation at surgical intervention $(p$-value $<0.001)$. There was a ststistically significant positive correlation between the amount of hemoperitoneum on sonography and the estimated 
volume of intraperitoneal blood at surgical intervention ( $p$-value <0.001). The research team of investigators the mean parameters of a hematosalpinx and the total outer mean diameter of an ectopic gestation on onographic assessment showed better statistical correlation better with the surgical findings than does the size of the chorionic cavity. The research results and findings reveal that the standard protocol of assessing the size of an intrauterine gestation on sonographic evaluation should be adjusted to involve these additional parameters in cases diagnosed clinically having tubal ectopic gestation $[\mathbf{4 , 9 , 1 8 , 4 2 ]}$

Another research study similar to the current research study in the aspect of investigating serum progesterone in which the research team of investigators assessed the efficiency of a progesteronebased algorithm for the management of cases having pregnancies of unknown location and investigate in addition the feasibility of developing a single-visit management strategy in clinical scenarios having a low risk of medical interventional management requirement. The investigators conducted their research by the following research methodology in which all clinically stable cases in were pregnancy could not be observed on sonographic scan have been managed by a predesigned protocol based on assay of serum progesterone level and beta-human chorionic gonadotropin hormone. Management intervention in the form of surgery or medical treatment by usage of methotrexate was administered to all cases having constant or clinical symptoms and non-decreasing serum level of beta-hCG. Decision-tree statistical analysis have been implemented to innovate a management protocol of cases with resolving gestations having a low risk of medical interventional requirement. The research team of investigators recruited 1110 cases in which they were integrated in the statistical data analysis: The following results were obtained in which normal intrauterine gestation was clinically diagnosed in 248 cases (22.3\%; 95\% CI, 19.9-24.8). 761 (68.6\%; 95\% CI, 65.8-71.3) abnormal gestations resolved spontaneously on expectant management, whereas the remaining 101 cases $(9.1 \%$; $95 \%$ CI, 7.4-10.8) having abnormal gestations required some form of medical interventional management. Intervention rates in cases clinically presenting with preliminary serum progesterone concentrations of $\leq 20 \mathrm{nmol} / \mathrm{L}$ and $\leq 10 \mathrm{nmol} / \mathrm{L}$, were $3.9 \%$ (95\% CI, 2.4-5.4) and $2.1 \%$ (95\% CI, 0.9-3.3), consecutively. In cases clinically presenting with Serum progesterone $\leq 10 \mathrm{nmol} / \mathrm{L}$ and beta $-\mathrm{hCG}<450 \mathrm{IU} / \mathrm{L}$, the rate of intervention was $1.3 \%$ (95\% CI, 0.2-2.5). The research team came to the conclusion that cases with pregnanacy of unkown locations with serum progesterone $\leq 10 \mathrm{nmol} / \mathrm{L}$ at clinical presentation are at low risk level of needing medical intervention and might not gain from attendance of regular follow-up clinical visits $[2,12,27,38]$

\section{Conclusions:}

Leash sign is a highly sensitive sonographic sign that could be implemented on widespread practice however other sonographic markers should be respected in integration with bio markers since there is no single sign or marker that could be applicable in all case scienarios.

\section{Recommendations:}

The future research studies should be conducted in a multicentric fashion with larger study populations integrating leash sigm as a sonographic marker with other biomarkers for ectopic pregnancy. That could aid in a medical algorithm performance that could aid in efficient diagnosis and management of ectopic pregnancy Future research efforts additionally should consider racial and ethnic differences that could affect the representation symptoms of the disease.

Molecular and genetic markers (e.g HOXA10 gene expression that shows at the site of ectopic implantation as compared with the endometrium and with the normal fallopian tube) should be investigated much more extensively in future research with integration of sonographic markers with statistical comparative analysis to help in future medical guideline innovation for more diagnostic power in the detection of early developing ectopic pregnancy.

\section{References}

1- R.V. RAMANAN and J. GAJARAJ: Ectopic Pregnancy the Leash Sign. A New Sign on Transvaginal Doppler Ultrasound Acta. Radiol., 47: 529-535, 2006.

2- SERPIL AYDO GMUŞ, HÜSEYIN AYDO GMUŞ , SERVET GENÇDAL and SEFA KELEKÇI1: Density of tubal ring vascularization: A new marker for prediction of success of medical treatment in tubal ectopic pregnancy European Journal of Obstetrics and Gynecology and Reproductive Biology, http://dx.doi.org/10.1016/ j.ejogrb.2017.08.022, 2017.

3- K. RAJAH, V. GOODHART, K.P. ZAMORA, T. AMIN, E. JAUNIAUX and D. JURKOVIC: How to measure size of tubal ectopic pregnancy on ultrasound Ultrasound Obstet. Gynecol., 52: 103-109 DOI: 10.1002/uog.18958, 2018.

4- A. DAY, E. SAWYER, D. MAVRELOS, A. TAILOR, S HELMY and D. JURKOVIC: Use of serum progesterone measurements to reduce need for follow-up in women with pregnancies of unknown location Ultrasound Obstet. Gynecol., 33: 704-710 DOI: 10.1002/uog.6380, 2009. 
5- AYIM F., TAPP S., GUHA S., et al.: Can risk factors, clinical history and symptoms be used to predict the risk of ectopic pregnancy in women attending an early pregnancy assessment unit? Ultrasound Obstet. Gynecol., Jul. 1. doi: 10.1002/uog.16007, 2016.

6- DOUBILET P.M., BENSON C.B., BOURNE T., et al.: Diagnostic criteria for nonviable pregnancy early in the first trimester. N. Engl. J. Med., 369 (15): 1443-1451, 2013.

7- BIRCH PETERSEN K., et al.: Cesarean scar pregnancy: a systematic review of treatment studies. Fertil Steril, 105 (4): 958-967, 2016.

8- BENSON C.B., DOUBILET P.M., PETERS H.E., et al. Intrauterine fluid with ectopic pregnancy: A reappraisal. J. Ultrasound Med., 32 (3): 389-393, 2013.

9- MAYMON R., SVIRSKY R., SMORGICK N., et al.: Fertility performance and obstetric outcomes among women with previous cesarean scar pregnancy. J. Ultrasound Med., 30 (9): 1179-1184. PubMed PMID: 21876087 , 2011.

10- BIRCH PETERSEN K., et al.: Cesarean scar pregnancy: a systematic review of treatment studies. Fertil Steril, 105 (4): 958-967, 2016.

11- MAYMON R., SVIRSKY R., SMORGICK N., et al.: Fertility performance and obstetric outcomes among women with previous cesarean scar pregnancy. J. Ultrasound Med., 30 (9): 1179-1184. PubMed PMID: 21876087 , 2011.

12- PARKER V.L., SRINIVAS M.: Non-tubal ectopic pregnancy. Arch. Gynecol. Obstet., 294: 19-27, 2016.

13- SALOMON L.J.Z., ALFIREVIC C.M., BILARDO G.E., et al.: ISUOG practice guidelines: performance of firsttrimester fetal ultrasound scan. Ultrasound Obstet. Gynecol., 41 (1): 102-113, 2013.

14- TIMOR-TRITSCH I.E., et al.: The diagnosis, treatment, and follow-up of cesarean scar pregnancy. Am. J. Obstet. Gynecol., 207 (1): 44.e1-44.e13, 2012.

15- DOUBILET P.M., BENSON C.B., BOURNE T., et al.: Diagnostic criteria for nonviable pregnancy early in the first trimester. N. Engl. J. Med., 369 (15): 1443-1451, 2013.

16- BENSON C.B., DOUBILET P.M., PETERS H.E., et al. Intrauterine fluid with ectopic pregnancy: A reappraisal. J. Ultrasound Med., 32 (3): 389-393, 2013.

17-KIRK E., BOTTOMLEY C. and BOURNE T.: Diagnosing ectopic pregnancy and current concepts in the management of pregnancy of unknown location. Hum. Reprod Update, 20 (2): 250-261, 2014

18- VAN CALSTER B., BOBDIWALA S., GUHA S., et al.: Managing pregnancy of unknown location based on initial serum progesterone and serial serum hCG: Development and validation of a two-step triage protocol. Ultrasound Obstet. Gynecol., 2016.

19- TIMOR-TRITSCH I.E., CALI G., MONTEAGUDO A., et al.: Foley balloon catheter to prevent or manage bleeding during treatment for cervical and Cesarean scar pregnancy. Ultrasound Obstet. Gynecol., 46 (1): 118-123, 2015.

20- TIMOR-TRITSCH I.E., MONTEAGUDO A., BENNETT T.A., et al.: A new minimally invasive treatment for cesarean scar pregnancy and cervical pregnancy. Am. J. Obstet. Gynecol., 215 (3): 351.e1-351.e8, 2016.

21- LEVIN I., TSAFRIR Z., SA'AR N., et al.: "Watchful waiting" in ectopic pregnancies: A balance between reduced success rates and less methotrexate. Fertil Steril, 95 (3): 1159-60, 2011.

22- HASAN R., BAIRD D.D., HERRING A.H., OLSHAN A.F., JOHNS SON FUNK M.L. and HARTMANN K.E.: Pattern and predictors of vaginal bleeding in the first trimester of pregnancy. Ann. Epidemiol., 20 (7): 524-31, 2010.

23- SHAUNIK A., KULP J., APPLEBY D.H., SAMMEL M.D., BARNHART K.T.: Utility of dilation and curettage in the diagnosis of pregnancy of unknown location. Am. J. Obstet. Gynecol., 204: 130-136, 2011.

24- MORSE C.B., SAMMEL M.D., SHAUKINA A., ALLENTAYLOR L., OBERFOELL N.L., TAKACAS P., CHUNG K., et al.: Performance of human chorionic gonadotropin curves in women at risk for ectopic pregnancy: Exceptions to the rules. Fertili Steril, 97 (1): 101-6, 2012.

25- DESAI D., LU J., WYNESS S.P., GREENE D.N., OLSON K.N., WILEY C.L. and GRENACHE D.G.: Human chorionic gonadotropin discriminatory zone in ectopic pregnancy: Does assay harmonization matter? Fertil Steril, 101 (6): 1671-4, 2014

26- BARNHART K.T., SAMMEL M.D., APPLEBY D., RAUSCH M., MOLINARO T., VAN CALSTER B., et al.: Does a prediction model for pregnancy of unknown location developed in the UK validate on a US population? Hum. Reprod, 25: 2434-40, 2010.

27- ZEE J., SAMMEL M.D., CHUNG K., TAKACS P., BOURNE T., BARNHART K.T.: Ectopic pregnancy prediction in women with a pregnancy of unknown location: Data beyond 48 hour are necessary. Hum. Reprod, 29 (3): 441-7, 2014.

28- HELMY S., BADER Y., PABLIK E., TIRINGER D., PILS S., LAMI T., KOBLIK H., et al.: Cut-off value of initial serum $\mathrm{p}$-hCG level predicting a successful methotrexate therapy in tubal ectopic pregnancy: A retrospective cohort study. Eur. J. Obstet. Gynecol. Reprod Biol., 179C: 175-80, 2014.

29- GUIBOURDENCHE J., HANDSCHUH K., TSATSARIS V., GERBAUD P., LEGUY M.C., MULLER F., BRION D.E. and FOURNIER T.: Hyperglycosylated hCG is a marker of early human trophoblast invasion. J. Clin. Endocrinol. Metab., 95: E240-244, 2010.

30- COLE L.A.: Hyperglycosylated hCG and pregnancy failures. J. Reprod Immunol., 93 (2): 119-22, 2012.

31- BUTLER S.A., ABBAN T.K., BORRELLI P.T., LUTTOO J.M., KEMP B. and ILES R.K.: Single point biochemical measurement algorithm for early diagnosis of ectopic pregnancy. Clin. Biochem., 46 (13-14): 1257-63, 2013.

32- RAUSCH M.E., SAMMEL M.D., TAKACS P., CHUNG K., SHAUNIK A. and BARNHART K.T.: Development of a multiple marker test for ectopic pregnancy. Obstet. Gynecol., 117 (3): 573-82, 2011.

33- DAPONTE A., DELIGEOROGLOU E., GARAS A., POURNARAS S., HADJICHRISTODOULOU C. and MESSINIS I.E.: Activin A and follistatin as biomarkers 
for ectopic pregnancy and missed abortion. Dis. Markers, 35 (5): 497-503, 2013.

34- WARRICK J., GRONOWSKI A., MOFFETT C., ZHAO Q., BISHOP E. and WOODWORTH A.: Serum activin A does not predict ectopic pregnancy as a single measurement test, alone or as part of a multi-marker panel including progesterone and hCG. Clin. Chim. Acta., 413 (7-8): 707-11, 2012

35- ELITO JÚNIOR J., GUSTAVO OLIVEIRA L., OCTÁVIO FERNANDES SILVA M., ARAUJO JÚNIOR E. and CAMANO L.: Serum activin A levels and tubal ectopic pregnancy. Iran J. Reprod Med., 12 (3): 227-8, 2014

36- WANG J., LIU S., QIN H.M., ZHAO Y., WANG X.Q. and YAN Q.: Pregnancy-associated plasma protein A upregulated by progesterone promotes adhesion and proliferation of trophoblastic cells. Int. J. Clin. Exp. Pathol., 7 (4): 1427-37, 2014.

37- HA C.T., WU J.A., IRMAK S., LISBOA F.A., DIZON A.M., WARREN J.W., ERGUN S. and DVEKSLER G.S.: Human pregnancy specific beta-1-glycoprotein 1 (PSG1) has a potential role in placental vascular morphogenesis. Biol. Reprod., 83 (1): 27-35, 2010.

38- VERHAEGEN J., GALLOS I.D., VAN MELLO N.M., ABDEL-AZIZ M., TAKWOINGI Y., HARB H., DEEKS J.J., MOL B.W.J. and COOMARASAMY A.: Accuracy of single progesterone test to predict early pregnancy outcome in women with pain or bleeding: Meta-analysis of cohort studies. BMJ, 345: e6077, 2012.

39- CHETTY M., SAWYER E., DEW T., CHAPMAN A.J. and ELSON J.: The use of novel biochemical markers in predicting spontaneously resolving 'pregnancies of unknown location'. Hum. Reprod, 26: 1318-23, 2011.

40- MARTÍNEZ-RUIZ A., SARABIA-MESEGUER M.D., PÉREZ-FORNIELES J., VÍLCHEZ J.A., TOVARZAPATA I. and NOGUERA-VELASCO J.A.: Placental growth factor, soluble fms-like tyrosine kinase 1 and progesterone as diagnostic biomarkers for ectopic pregnancy and missed abortion. Clin. Biochem., 47 (9): 844 7. Biomarkers of Ectopic Pregnancy-Present and Future http://dx.doi.org/10.5772/5895471. 2014.

41- FENG C., CHEN Z.Y., ZHANG J., XU H., ZHANG X.M. and HUANG X.F.: Clinical utility of serum reproductive hormones for the early diagnosis of ectopic pregnancy in the first trimester. J. Obstet. Gynaecol. Res., 39 (2): 52835, 2013.

42- ZOU S., LI X., FENG Y., SUN S., LI J., EGECIOGLU E., BILLIG H. and SHAO R.: Comparison of the diagnostic values of circulating steroid hormones, VEGF-A, PIGF, and ADAM12 in women with ectopic pregnancy. J. Transl. Med., 11: 44, 2013.

\title{
دور البروجيستيرون المصلى وعلامة الشرنته بالسونار

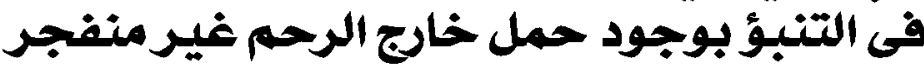

\begin{abstract}
الام أسفل البطن والنزف المهبلى في أول الحمل من المشاكل الصحية الثائعة، تكمن الخطودة في اشتباه حدوث حمل خارج الرحم. عدم

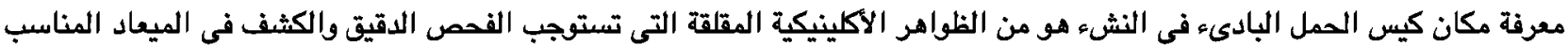

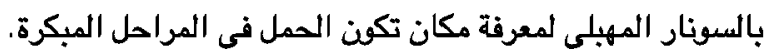

الحمل خارج الرحم هو من الأمراض التى تهدد حياة المريضة ازا لم يتم أكتشافه مبكراً از أنه قد يؤدى إلى حدوث نزيف داخلى قدئ قد يكون

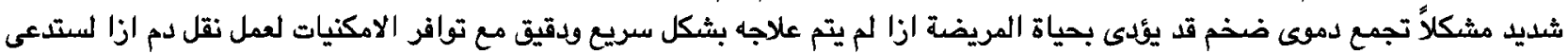
الامر.

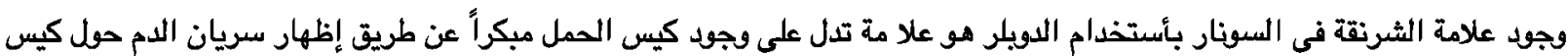

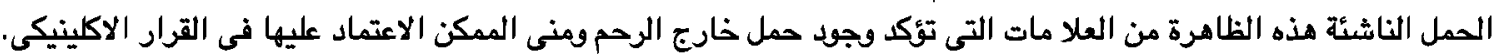

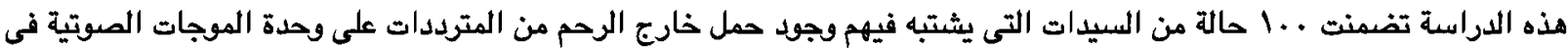

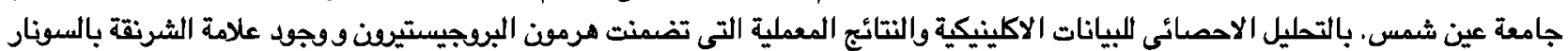
تبين الكفاءه الاحصائية العالية لعلامة الشرنقة وحدها أكثر من هرمون البروجيستيرين.

من الاستتتاجات المأخوذة من البحث ان علامة الشرنقة هى من العلامات الهامة والموثوق فيها للتنبؤ بالحمل خارج الرحم وتساعد على

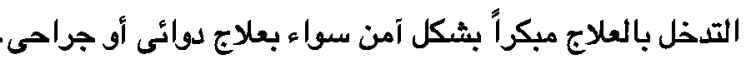

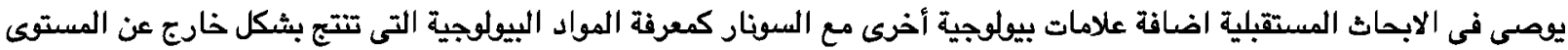

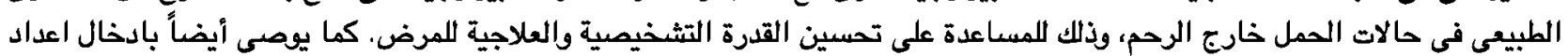

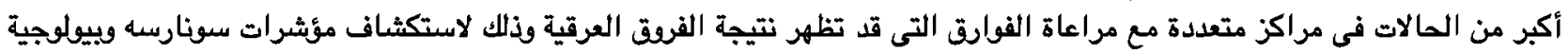

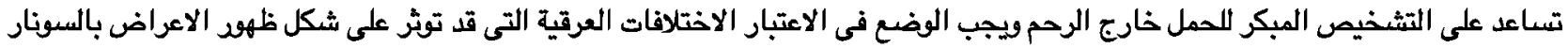

